\title{
Managing emerging challenges of Coronavirus disease 2019 (COVID-19) in dentistry
}

Dental centers have been referred to as a hub or reservoir for infection, where healthcare professionals and other staff, patients and the public together may potentially spread pathogenic microorganisms. This may occur via saliva, skin or indirectly through air, water, and contaminated surfaces or instruments. Everyone should therefore be considered as potential sources of infection. During a pandemic, limiting unnecessary care has been adopted as a clinical measure for some patient's, to reduce the risk of cross-infection in the short term. However, in order to enable continuation of necessary and qualified care, dental processes need to follow specific infection control strategies in order to prevent transmission of emerging pandemic risks following COVID-19. In this article, we develop a tool with practical recommendations to mitigate infection risks before, during and following pandemics to enable ongoing dental care provision in primary and secondary care based on national and global recommendations.

Keywords: COVID-19, Protection measures, Dentistry, Transmission routes, Cross-infection

\section{Introduction}

In December 2019, the outbreak of Acute Respiratory Disorder Syndrome Corona Virus 2 (SARS-Cov2), or Corona Virus Disease 2019 (COVID-19), started in China-Wuhan. The World Health Organization (WHO) officially announced the outbreak as a pandemic on March 12, 2020 (1). Since the virus was discovered, cases spread worldwide have caused one of the biggest and most complex infection outbreaks in history. COVID-19 spreads mainly through symptomatic or asymptomatic persons and effectively through breathing (2-5). For this reason, it has been reported that healthcare professionals, family members, friends and patients who are in close contact with COVID-19 persons are at risk of getting infected or spreading the virus $(6,7)$. Although, it is stated that the mortality rate of COVID-19 is lower than other Corona Virus diseases, the problem is the very rapid transmission of disease and that increasing numbers of infected persons complicate survival (3-5).

Dental Care Professionals are exposed to pathogenic microorganisms that infect the oral cavity and respiratory tract, both because they work in the oral area, they cannot maintain an advised global 1-meter public distance (2). In light of the current Coronavirus Pandemic (COVID-19), people working in this area are subject to considerable risk of contamination with COVID-19 due to face-to-face interactions and contact to saliva, blood, other secretions, and use of sharp instruments. In addition, inhalation of aerosols and airborne particles, especially during applications using ultrasonic and high-speed dental handpiece, poses an additional higher risk of contamination for COVID-19 (2).

\author{
Gülsüm Ak' ${ }^{1}$, \\ Aysem Y. Gunay ${ }^{1} \mathbb{D}$, \\ Ryan C. Olley ${ }^{2,3}$ (D), \\ Nazmiye Sen ${ }^{4}$
}

ORCID IDs of the authors: G.A. 0000-0002-3339-1568; A.Y.G. 0000-0002-1161-1005; R.O. 0000-0002-1178-5013; N.Ş. 0000-0003-2768-2112

${ }^{1}$ Department of Oral and Maxillofacial Surgery, School of Dentistry, University of Istanbul, Istanbul, Turkey

${ }^{2} S$ chool of Dentistry, Cardiff University and University Hospital of Wales, Cardiff, United Kingdom

${ }^{3}$ Faculty of Dentistry, Oral and Craniofacial Sciences, Kings College London, UK

${ }^{4}$ Department of Prosthodontics, School of Dentistry, University of Istanbul, Istanbul, Turkey

Corresponding Author: Nazmiye Sen E-mail: nazmiye.sonmez@istanbul.edu.tr

Received: 09 May, 2020 Revised: 19 May, 2020 Accepted: 21 May, 2020 
Emerging challenges of coronavirus disease 19 (COVID-19) in dentistry

The COVID-19 outbreak throughout populations and, perhaps more specific to dentistry, intraoral secretions containing high concentrations of virus, are themselves important indicators that the working dental environment is dangerous (2). The findings of previous studies show that angiotensin converting enzyme II (ACE2) plays an important role in the cellular entry of virus $(8,9)$. ACE2 is found in the oral mucosa, especially in the tongue intensely (10). These findings indicate that COVID-19 causative virus will bind to ACE2s located in the oral cavity and increase the susceptibility to infection (8-10). It is emphasized that virus density and duration of contact have an important role on the transmission and course of the disease $(7,8,11)$. Despite the protection measures of healthcare professionals serving during the epidemic period, the number of deaths amongst high risk individuals high (6). High risk individuals may include, for example, the elderly over 70 years of age, the systemically medically compromised, in particular the immune-compromised and cardio-respiratory compromised, and pregnant patients, in particular those in the third trimester (2). In addition, it is known that the number of infected individuals who do not show clinical symptoms are as much as the individuals who have clinical symptoms $(12,13)$. Therefore, there exists a hidden risk that individuals who do not show clinical symptoms and are unaware of their infection, have the potential to spread the virus (14-16).

COViD-19, currently does not have a specific antiviral treatment or vaccine available, but Phase I clinical trials with the most advanced COVID-19 vaccine candidates began in the spring of 2020 worldwide. Current treatment includes some of the antiviral drugs used for other viral diseases, and plasma replacement therapy which provides general care to support vital organ functions (17-19). Effective disinfectant and antiseptic products are essential to prevent the spread of infection in the absence of COVID-19-specific treatments, and particularly in diseases with a high rate of transmission. In addition, hygienic measures such as wearing medical masks, protective glasses or face shields to reduce the passage through breathing are very important for protection against COViD-19 contamination (20). Because COVID-19 is a deadly threat, the use of antiseptics with antiviral activity is critical to help prevent contamination. However, although enveloped viruses like Corona virus are considered to be more sensitive to antiseptics, they may react differently than non-enveloped viruses in terms of the concentration of the active ingredient and the required duration of administration $(21,22)$. Enveloped viruses are responsible for serious outbreaks such as acute respiratory failure syndrome (SARS), Middle East respiratory syndrome coronavirus (MERS-CoV), and ebola virus disease (EBOV). The recent Corona virus (COVID-19) outbreak emphasizes the importance of prevention measures to help prevent infection and limit the spread of disease before, during and following a pandemic $(15,17)$.

Employees and the public are therefore at high risk for infection in dentistry (2). Infection is defined as a clinical picture resulting from inflammatory reactions caused by entrance of a microorganism into the body with response from the body's immune system (23). This response may occur in a specific body area or more systematically. The best method of prevention is therefore to stop the microorganism at the cross-infection stage. Cross infection is the transition of pathogenic microorganisms from an infected person to a non-infected person that may potentially cause infection (24). In dental practices, cross infections occur either directly (person-to-person), indirectly (for example using a contaminated / non-sterilized instrument in another patient), or by droplet infection (inhalation of microorganisms suspended in the air) (23-25). The lack of necessary precautions can be responsible for the transmittance of the infection factor. COVID-19 infected persons may be grouped as individuals with symptoms that are easily recognized at the acute stage of infection and individuals without symptoms that can only be recognized by tests. In the case of a pandemic, to avoid delay in necessary clinical care provision, every person may be seen as a potential carrier regardless of the health history $(2,17)$.

Infection control measures for all patients in dentistry during a pandemic

Clinical staff must protect themselves and the other patients from the source of infection in the clinical setting $(7,11,14)$. In addition, the dentist should be alert to infectious diseases that they might encounter, and direct his patient for necessary medical treatment before dental treatment (24). Due to the risk of mortality, dental healthcare professionals who are in contact with a large number of people should have high awareness of this issue. In this section, infection control measures are described for dentistry in general. Nonetheless, it is important for dental centers to continue to follow national and regional advice from governments and clinical networks.

\section{Hand hygiene}

Hand hygiene has become even more prevalent for dental practice during the COVID-19 pandemic. In fact, a regimen has been suggested for 5 handwashes, 2 prior to treatment and 3 following (14). Specially, clinicians should wash their hands before examining the patient, before dental treatment, after contacting to patient, after touching infected settings and instruments, and after touching the oral mucosa, open wound surface or any fluid associated with the patient. The dental professionals should be given more care to avoid contacting their mouth, nose and eyes $(2,12,13)$. These recommendations go beyond the clinical handwashing protocol outside of a pandemic situation.

\section{Patient triage}

The general consensus is that triage should be conducted in order to examine the existing state of health and the existence of risk factors for COVID-19 progression while accepting patients $(13,26)$. This may be conducted initially by phone by an appropriately trained member of staff in order to investigate dental and medical needs using structured questions $(26,27)$. This may identify high risk patients or assess the vulnerability of patients and threat they may pose to other patients or staff in the practice (5). This should be handled empathetically and so as to not prejudice. Patients 
may be questioned whether they have had any interaction with persons who are infected or whether they have flown to high outbreak regions. If the patient has a history of contact and symptoms, treatment should not be performed and the patient should be directed to the relevant institutions for quarantine or hospitalization, dependent on national guidelines (14). It is advised that dental procedures be delayed for 14 days, which is the quarantine time for asymptomatic patients. Dental operations can be carried out in the absence of contact, symptoms, travel records by taking preventive measures. It is critical for those who accompany the patient to have the same protection measures implemented $(26,27)$.

On presentation of the patient and other persons to the surgery, body temperature should be measured with a contactless thermometer on the forehead, and the presence/ absence of abnormal symptoms such as cough, sneezing or difficulty in breathing should be evaluated $(2,13)$. National guidelines should be followed and if the patient is likely to have viral infection, treatment delayed.

\section{Application of only emergency and mandatory treatments}

Emergency and mandatory treatments to be applied in dentistry in Turkey have been reported by the Ministry of Health. The list is in accordance with the guidance of Centers for Disease Control and Prevention (CDC) for providing Dental Care during COVID-19 $(26,27)$. These treatments include:

a. Severe toothache caused by pulpal inflammation

b. Severe pain from pericoronitis or third molar

c. Postoperatively developing osteitis or alveolitis

d. Abscess or bacterial infection that causes localized pain and swelling

e. Tooth fracture causing pain or soft tissue trauma

f. Avulsion or luxation injuries due to dental trauma

g. Fractures of the jaw and face

h. Painful lesions / ulcerations of the oral mucosa

i. Life-threatening or uncontrolled bleeding

j. Intraoral / extraoral infections that threaten the patient's airway patency

k. Treatment of patients who are planned to receive, or are receiving, radiotherapy and chemotherapy and planned to take organ transplantation

I. Patients requiring dental consultation for medical problems m. Suture removal

$\mathrm{n}$. Treatment of temporary restoration losses/fractures and ulcerations of removable dentures so as not to form aerosols

o. Pain and / or infection due to injury in soft tissue as a result of fracture of brackets and wires of patients undergoing orthodontic treatment

p. Feeding plate applications of newborn patients with cleft lip and/or palate

q. Temporomandibular luxation

r. Biopsy (in cases of suspected malignancy)

Treatments other than the above procedures may be delayed based on national guidelines. It is recommended that emergency treatments be implemented by certain staff in isolated areas, and ensuring the temperature and health of all staff are monitored.

\section{Instrument and surface decontamination}

Contaminated areas such as common areas, door handles, chairs and tables, and instruments contaminated by patient fluids such as blood and saliva should first be cleaned and then disinfected. Disinfection should not be applied without cleaning $(28,29)$. All areas should be dry and ventilated (30). For cleaning and disinfection, national guidelines may be followed. In the Ministry of Health Guide in Turkey, the following have been proposed (26),

1. Sodium hypochlorite 1:10 diluted standard bleach for blood and body fluids contaminated surfaces;

2. Sodium hypochlorite 1: 100 diluted standard bleach for external surfaces;

3. $0.5 \%$ hydrogen peroxide for exterior surfaces of equipment, floors and walls;

4. Quaternary ammonium compounds for floors and walls.

5. Elevators should be regularly disinfected, people using elevators should wear masks correctly and avoid direct contact with touch buttons if possible (2)

\section{Personal protective equipment}

In dental clinics and hospitals, personal protection equipment including goggles, masks, gloves, caps, face shields, and protective outerwear, is strongly recommended for all healthcare providers, especially as airborne droplet transmission is considered the main route of spread $(13,14)$. When wearing and taking off personal protective equipment, caps, protective outwear, masks, goggles, face shields and gloves should be donned in order. While taking off, attention should be paid to the order of gloves, face shields, googles, protective outwear, caps and masks (30,31). Protective outwear should have long sleeves and made of liquid impervious fabric (30). Caps, googles, face shields and masks must be used by all staff. Googles and face shields should be cleaned with soapy water after each patient and wiped with at least $70 \%$ alcohol-based disinfectant. If glove integrity is impaired or contamination occurs, gloves should be removed immediately, and after hand hygiene is provided new gloves should be worn (30).

In regard to masks specifically, they may be described in terms of levels according to their degree of infection prevention (32). Level 1 masks have the least fluid resistance, bacterial filtration efficiency, particulate filtration efficiency, and breathing resistance. Level 2 masks provide a moderate barrier for fluid resistance, bacterial and particulate filtration efficiencies and breathing resistance. Level 3 masks provide the maximum level of fluid resistance recognized by American Society of Testing and Materials (ASTM) and are designed for procedures with moderate or heavy amounts of blood, fluid spray or aerosol exposure (33). Furthermore, according to American Dental Association (ADA), there are 3 different types of masks (Table 1) including surgical masks, N95 and N95 equivalent masks (KN/KP95, PFF2, P2, DS/DL2, Korean Special $1^{\text {st }}$ ). N95 and N95 equivalent masks are recommended when treating patients during this pandemic.

Masks should fit the face and be used with other protective equipment. If the masks are not used with goggles or face shields, it is strongly indicated that there is a higher risk 


\section{USA Standard}

Mask Types

European standard

(EN 149:2001)
Evaluated, tested, and approved by National Institute for Occupational Safety and Health

(NIOSH)

\section{Protection for healthcare professionals against COVID-19}

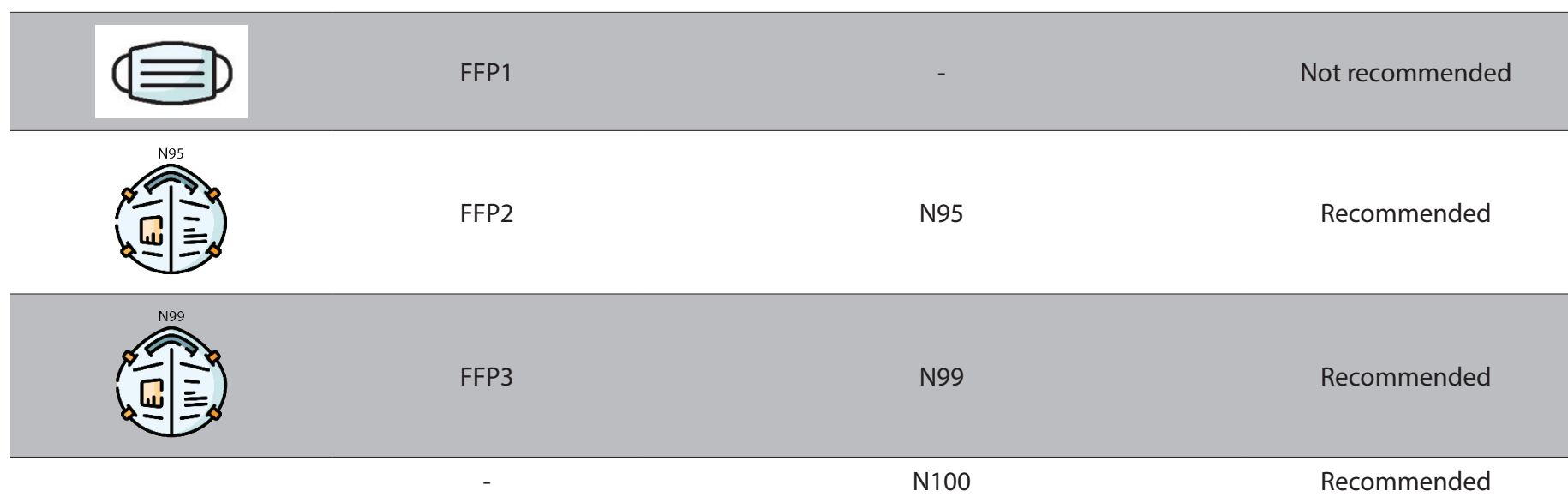

of infection $(27,33)$. It should not be neglected to remove the mask lastly after leaving the patient infected zone and then to apply hand hygiene (33).

Reduce reliance on aerosol production and ensure effective Aspiration-Ventilation

During the pandemic, procedures that produce aerosols should be avoided, for example use of high-speed handpieces and ultrasonic devices. Techniques such as Atraumatic Restorative Technique (ART) with Glass lonomers may be more useful temporary or intermediate term options for restorations than conventional composites that involve aerosol production $(13,34,35)$. Therefore, treatment may be applied with manual instruments if possible. If handpieces are used, devices with an anti-retraction valves should be used together with high-volume aspirators and the procedure undertaken with the 4-hand technique $(2,7,13)$.

The use of rubber-dam may also significantly reduce the formation of aerosol or droplet contaminated with saliva and blood. It has been reported that the use of rubber-dam can reduce particles in the air of the operation area with a diameter of about $90 \mathrm{~cm}$ by $70 \%$. High-volume aspirators should be preferred during application and four hand technique should be used $(2,7)$.

Additionally, it is recommended to use mouthwashes containing oxidative agents such as $1 \%$ hydrogen peroxide or $0.2 \%$ povidone, instead of routine antimicrobial mouthwashes (26). It is important to use mouthwashes especially for situations where rubber dam cannot be used.

\section{Safe waste management}

Medical wastes should be removed in accordance with the "Control of Medical Wastes" regulation of Ministry of Environment And Urbanization (36-38). In patients with no suspected infection, red colored plastic bags with black colored "International Biohazard" emblem on both sides and "ATTENTION! MEDICAL WASTE" writing should be used. In patients with suspected infection or the presence of infection, red colored plastic storage containers with black colored "International Biohazard" emblem and a black "CAUTION! PATHOLOGICAL MEDICAL WASTE" writing should be used (37).

\section{Infection control education}

Education and Training Staff and supervisors who are involved in the decontamination process should have demonstrated knowledge of national processes and infection control principles (38).

\section{Additional infection control measures for COVID-19 patients in dentistry}

Because of these features of dental treatment in which a large number of droplets and aerosols may be produced over a wide area; routine infection control precautions are not adequately efficient in regular clinical practice to control the spread of COVID-19. This problem is particularly compounded when patients are in the incubation phase, are unaware of having being exposed to or want to conceal their disease (12). As a general rule, the treatment of an infected or at-risk patient should be postponed until the patient's active symptoms disappear. The patient should proceed to his dental treatment after receiving necessary treatment for the infection. Apart from these, in exceptional circumstances where a COVID-19 patient requires care, the following rules should be observed in addition to the aforementioned infection control measures:

- COVID-19 patients should be given the last appointment of the day in order to allow aerosols to be neutralized overnight.

- Body temperature should be measured with a contactless thermometer on the forehead.

- Attention should be paid to carry out the dental treatments in a predetermined part of the clinic.

- Protective protection covers should be applied to all water and air spray guns, aerator heads of the unit and other exposed surfaces that are not used clinically 
- Unit table, control buttons and reflector arms should be covered with disposable covers.

- The dental clinic and preoperative area reserved for patients with COVID-19 should be ventilated with negative pressure systems and the negative pressure level should be checked. In hospitals where there are no negative pressure systems, positive pressure systems and air conditioners should be closed.

- $\quad$ Going outside with any aprons worn in clinics should be prevented.

- In the case of x-ray; related apparatus should be covered with disposable plastic and taking panoramic radiography should be preferred instead of periapical radiography.

- All touched surfaces should be cleaned with effective disinfectants including flooring, walls and ceilings,

- $\quad$ Prior to taking the patient to the dental unit, all tools that will not be used should be removed.

- $\quad$ All staff in addition to patient and all healthcare professionals should wear a disposable gown and masks.

- Side protection goggles, gloves and surgical mask should be used,

- Disposable instruments should be used in risky patients as much as possible,

- If necessary, double gloves should be used according to the length of the procedure,

- The treatment should be completed as quick as possible, and unnecessary personnel should not be taken into the clinic.

- $\quad$ Surfaces should be disinfected after cleaning with appropriate detergent.

- Hands should be washed with antiseptic solution.

- The materials that are discarded after use should be collected by putting 'septic material' on them by placing the sharp ones in thick and safe protectors $(26,30,37,38)$.

Recommended approaches to primary and secondary dental care during pandemics

As the pandemic continues or is brought under control in various countries, there remains possibility of second waves of COVID-19 or re-emergence of disease $(39,40)$. Therefore, it is likely that the recommendations discussed in this article will need to continue for some time beyond the end of the pandemic phase of an infection. This will require adaptations to the way dentistry is provided in primary care and methods for provision of secondary or specialist care to support ongoing clinical care in practice in challenging situations. It will also be important to focus care towards prevention rather than operative. If possible, some less important treatment may be delayed until after the pandemic phase. In the UK, recommendations for prevention of dental disease and improving access through developing Managed Academic Clinical Networks (MACN) have been published (40).

With regard to secondary care provision, in the authors experience, appointments often necessitate a physical second dental visit and consultation with a specialist, with additional contact required between patients, staff and health care professionals. In this regard, the emerging era of digital dentistry may enable new opportunities during a pandem- ic for remote appointments to take place in certain clinical situations. One study assessed the viability of remote clinical consultations for the management of referrals from primary or general dental practitioners in restorative dentistry, compared to an in-person consultation with the patient also attending a secondary care environment, such as another dental practice or hospital (34). It found that remote consultations, using digital technologies, were as effective and safe as in-person consultations and had high patient acceptance. Moving on from this work, it may be possible for patients with dental care needs (who themselves are at higher risk of disease or carry an infection) to attend an appointment at a dedicated hub or site with the necessary infection control measures discussed above. Information from the examination and images from special tests may then be safely and effectively shared remotely and live with specialists at a safe distance, enabling simple and practical guidance for complex clinical care if required.

The high concern of second wave pandemic reveals the importance of the continuity of measures taken during and after the pandemic $(39,40)$. It is clear that adding the fever measurements to routine protocol will be effective to reduce the potential transmission risk. As of today's knowledge, support should be obtained from the current technologies for patient intervention, treatment process and keeping the environment clean. In prosthetic applications, it is preferred to use digital impression, if possible, to reduce the risk of long contact with saliva or transfer to the surfaces. Applications such as ozone, ultraviolet in line with the scientific study results for the sterilization of the environment should be utilized between patient intervals. Utilization of ceilings or floor instruments providing vacuum in addition to collecting the aerosol spread in the environment would be helpful during the treatment of these patients. As the oronasal way is known to be the primary road of transmission, the use of a mask covering only the nose of the patient during treatment could also be beneficial. This measure may increase the effectiveness of the protection of clinician while working at a short distance. It could also be predicted that the use of newly developed antiviral mouthwashes by physicians, patients, healthcare professionals, individuals with high risk, and their addition to the water supply coming to the dental unit may reduce the risk of transmission. The fact that pandemic is so effective all over the world will definitely lead to an increase in some measures and the development of new technologies in dentistry. For example, the development of non-aerosol devices.

\section{Conclusion}

The recent COVID-19 outbreak shows that all people are considered potential carriers of high-risk infection. It is therefore important to ensure routine and additional implementation of infection control procedures and adaptation of methods of dental care delivery in order to reduce risks of cross-infection and enable continuation of dental care provision. The recommendations discussed in this article, provide a tool for implementation of infection control and dental care delivery by dental healthcare professionals before, during and following an infection pandemic. In addition to routine measures, it is important to include the measures implemented during the epidemic in routine protocols. 
Türkçe Özet: Diş Hekimliğinde Coronavirüs 2019 hastalığı (COVID-19) nedeniyle ortaya çıkan zorlukları yönetmek. Diş klinikleri; sağlık profesyonelleri, yardımc personel, hastalar ve hasta yakınlarının birarada bulunduğu ve potansiyel olarak patojenik mikroorganizmaların yayılabileceği enfeksiyon riski konusunda riskli merkezler olarak görülmektedir. Çapraz enfeksiyon, tükürük, deri veya dolaylı olarak hava, su ve kontamine yüzeyler veya aletler yoluyla meydana gelebilmektedir. Bu nedenle, bireyler, potansiyel enfeksiyon kaynakları olarak düşünülmelidir. COVID-19 pandemisi sırasında, kısa vadede, çapraz enfeksiyon riskini azaltmak için bazı tedavilerin ve klinik uygulamaların önlem olarak sınırlandırılması benimsenmiştir. Bununla birlikte, gerekli ve nitelikli bakımın sürdürülebilmesi için dental tedavi süreçlerinin COVID-19'dan sonra da enfeksiyon risklerini önlemek için spesifik enfeksiyon kontrol stratejilerini takip etmesi gerekmektedir. Bu makalede, pandemiden önce, pandemi sırasında ve sonrasında enfeksiyon risklerini azaltmak için, ulusal ve küresel önerilere dayanarak birinci ve ikinci basamakta sürekli diş hekimliği hizmetlerinin sağlanmasına olanak tanıyan pratik öneriler sunulmaktadır. Anahtar Kelimeler: COVID-19, Korunma önlemleri, Diş Hekimliği, Bulaş yolları, Çapraz enfeksiyon

Ethics Committee Approval: Not required.

Informed Consent: Not required.

Peer-review: Externally peer-reviewed.

Author contributions: GA, AYG and NS designed the study. GA, AYG and NS participated in generating the data for the study. AYG, RCO and NS participated in gathering the data for the study. NS participated in the analysis of the data. GA, AYG and NS wrote the majority of the original draft of the paper. RCO and NS participated in writing the paper. All authors approved the final version of this paper.

Conflict of Interest: The authors had no conflict of interest to declare.

Financial Disclosure: The authors declared that this study has received no financial support.

\section{References}

1. WHO. WHO Characterizes COVID-19 as A Pandemic. World Health Organization. [accessed 12 March 2020]. [CrossRef]

2. Peng X, Xu X, Li Y, Cheng L, Zhou X, Ren B. Transmission routes of 2019-nCoV and controls in dental practice. Int J Oral Sci 2020;12:9. [CrossRef]

3. Chen N, Zhou M, Dong X, et al. Epidemiological and clinical characteristics of 99 cases of 2019 novel coronavirus pneumonia in Wuhan, China: a descriptive study. Lancet 2020;395:507-13. [CrossRef]

4. The Lancet. Emerging understandings of 2019-nCoV. Lancet 2020;395:311. [CrossRef]

5. Huang C, Wang Y, Li X, et al. Clinical features of patients infected with 2019 novel coronavirus in Wuhan, China. Lancet 2020;395:497-506. [CrossRef]

6. Chen H, Guo J, Wang $C$, et al. Clinical characteristics and intrauterine vertical transmission potential of COVID-19 infection in nine pregnant women: a retrospective review of medical records. Lancet 2020;395:809-15. [CrossRef]

7. Li Q, Guan X, Wu P, et al. Early transmission dynamics in Wuhan, China, of novel coronavirus-infected pneumonia. N Engl J Med 2020;382:1199-207. [CrossRef]

8. Xu H, Zhong L, Deng J, et al. High expression of ACE2 receptor of 2019-nCoV on the epithelial cells of oral mucosa. Int J Oral Sci 2020;12:1-8. [CrossRef]

9. Chen D, Li X, Song Q, Hu C, Su F, Dai J. Hypokalemia and Clinical Implications in Patients with Coronavirus Disease 2019 (COVID-19). medRxiv 2020; [Epub ahead of print]. [CrossRef]

10. Ge Z yu, Yang L ming, Xia J jia, Fu X hui, Zhang Y zhen. Possible aerosol transmission of COVID-19 and special precautions in dentistry. J Zhejiang Univ Sci B 2020; [Epub ahead of print]. [CrossRef]

11. To KKW, Tsang OTY, Chik-Yan Yip C, et al. Consistent detection of 2019 novel coronavirus in saliva. Clin Infect Dis 2020; [Epub ahead of print]. [CrossRef]

12. WHO. Global Surveillance for human infection with coronavirus disease (COVID-19). Interim Guid. Published online 2020. [accessed 12 May 2020]. [CrossRef]

13. Meng L, Hua F, Bian Z. Coronavirus Disease 2019 (COVID-19): Emerging and Future Challenges for Dental and Oral Medicine. J Dent Res 2020;99:481-7. [CrossRef]

14. WHO. World Health Organization holds news conference on the coronavirus outbreak. 16 March 202011 a.m. EDT. [CrossRef]

15. Chan JFW, Yuan S, Kok KH, et al. A familial cluster of pneumonia associated with the 2019 novel coronavirus indicating personto-person transmission: a study of a family cluster. Lancet 2020;221:1757-61. [CrossRef]

16. Rothe C, Schunk M, Sothmann P, et al. Transmission of 2019NCOV infection from an asymptomatic contact in Germany. N Engl J Med 2020;382:970-1. [CrossRef]

17. Wax RS, Christian MD. Practical recommendations for critical care and anesthesiology teams caring for novel coronavirus (2019-nCoV) patients. Can J Anesth 2020;67:568-76. [CrossRef]

18. Marano G, Vaglio S, Pupella S, et al. Convalescent plasma: New evidence for an old therapeutic tool? Blood Transfus 2016;14:152-7.

19. Li H, Zhou Y, Zhang M, Wang H, Zhao Q, Liu J. Updated approaches against SARS-CoV-2. Antimicrob Agents Chemother 2020; [Epub ahead of print]. [CrossRef]

20. Marui VC, Souto MLS, Rovai ES, Romito GA, Chambrone L, Pannuti CM. Efficacy of preprocedural mouthrinses in the reduction of microorganisms in aerosol: A systematic review. J Am Dent Assoc 2019;150:1015-26.e1. [CrossRef]

21. Eggers $M$, Koburger-Janssen $T$, Eickmann $M$, Zorn J. In Vitro Bactericidal and Virucidal Efficacy of Povidone-lodine Gargle/ Mouthwash Against Respiratory and Oral Tract Pathogens. Infect Dis Ther 2018;7:249-59. [CrossRef]

22. Steinmann J, Paulmann D, Becker B, Bischoff B, Steinmann E, Steinmann J. Comparison of virucidal activity of alcohol-based hand sanitizers versus antimicrobial hand soaps in vitro and in vivo. J Hosp Infect 2012;82:277-80. [CrossRef]

23. Yüzbasioglu E, Saraç D, Canbaz S, Saraç YS, Cengiz S. A survey of cross-infection control procedures: Knowledge and attitudes of Turkish dentists. J Appl Oral Sci 2009;17:565-9. [CrossRef]

24. Kelsch N, Davis CA, Essex G, Laughter L, Rowe DJ. Effects of mandatory continuing education related to infection control on the infection control practices of dental hygienists. Am J Infect Control 2017;45:926-8. [CrossRef]

25. Akpınar,Y.Z., Uzun, İ.H., Yılmaz, B., Tatar, N. Protetik Tedavilerde Çapraz Enfeksiyon Kontrolü. J Dent Fac Atatürk Uni 2013;7:142-9.

26. Kamu Hastaneleri Genel Müdürlüğü Sağlık Hizmetleri Dairesi Başkanlığı Ankara: Sağlık Bakanlığı [accesed 7 May 2020] [CrossRef]

27. Centers for Disease Control and Prevention (CDC). Recommended Guidance for Extended Use and Limited Reuse of N95 Filtering Facepiece Respirators in Healthcare Settings [internet]. Atlanta: [accessed 7 May 2020]. [CrossRef]

28. LiY, Wong T, Chung J, et al. In vivo protective performance of N95 respirator and surgical facemask. Am J Ind Med 2006;49:105665. [CrossRef]

29. Wang D, Hu B, Hu C, et al. Clinical Characteristics of 138 Hospitalized Patients with 2019 Novel Coronavirus-Infected Pneumonia in Wuhan, China. J Am Med Assoc 2020; [Epub ahead of print] Available from: doi: 10.1001/jama.2020.1585. [CrossRef]

30. Izzetti R, Nisi M, Gabriele M, Graziani F. COVID-19 Transmission in Dental Practice: Brief Review of Preventive Measures in Italy. J Dent Res 2020; [Epub ahead of print]. [CrossRef] 
31. Prati C, Pelliccioni GA, Sambri V, Chersoni S, Gandolfi MG. COVID-19: its impact on dental schools in Italy, clinical problems in endodontic therapy and general considerations. Int Endod J 2020;53:723-5. [CrossRef]

32. Lee SA, Hwang DC, Li HY, Tsai CF, Chen CW, Chen JK. Particle size-selective assessment of protection of european standard FFP respirators and surgical masks against particles-tested with human subjects. J Healthc Eng 2016;2016. [CrossRef]

33. Chau JPC, Thompson DR, Lee DTF, Twinn S. Infection control practices among hospital health and support workers in Hong Kong. J Hosp Infect 2010;75:299-303. [CrossRef]

34. Darwish S. COVID-19 Considerations in Dental Care. Dent Update 2020;47:287-302. [CrossRef]

35. Olley RC, Frost BEM PM. Clinical and academic recommendations for primary dental care prosthodontics. Br Dent J 2019;227:4515. [CrossRef]
36. American Dental Association (ADA), COVID-19 Safety and Clinical Resources. [Accessed 7 May 2020]. [CrossRef]

37. Centers for Disease Control and Prevention (CDC). Infection Prevention \& Control Guidelines \& Recommendations. Atlanta: [accessed 7 May 2020]. [CrossRef]

38. Siegel JD, Rhinehart E, Jackson M, Chiarello L. Guideline for Isolation Precautions: Preventing Transmission of Infectious Agents in Health Care Settings. Am J Infect Control 2007;35:S65164. [CrossRef]

39. Xu S, Li Y. Beware of the second wave of COVID-19. Lancet 2020;395:1321-2. [CrossRef]

40. Martin N, Shahrbaf S, Towers A, Stokes C, Storey C. Remote clinical consultations in restorative dentistry: a clinical service evaluation study. Br Dent J 2020;228:441-7. [CrossRef] 